\title{
Giant cutaneous (keratotic) horn on the thumb
}

\author{
Manojit Midya, ${ }^{1}$ Neeraj K Dewanda, ${ }^{2}$ Ranjit Kumar Sahu ${ }^{1}$
}

${ }^{1}$ Burns and Plastic Surgery, All India Institute of Medical Sciences, Jodhpur, India ${ }^{2}$ Department of General Surgery, Government Medical College, Kota, India

Correspondence to Dr Ranjit Kumar Sahu, drsahuplastikos@gmail.com

MM and NKD contributed equally.

Accepted 21 May 2019

\section{DESCRIPTION}

Cutaneous (keratotic) horn $(\mathrm{CH})$ is a benign, elongated, keratinous projection usually few millimetres from the skin surface. ${ }^{1-5}$ Few cases of giant $\mathrm{CH}$ $(\mathrm{GCH})$ have been reported in English literature. We present a rare interesting case of $\mathrm{GCH}$ on the thumb in a woman.

A 60-year-old female farmer presented with a black projectile growth on her right thumb for last 5 years. She had undergone excision of the same lesion 3 years back with recurrence at the same site. On examination, there was a $6 \times 1 \mathrm{~cm}$ long curved, blackish, elongated growth near the ulnar side of the right thumb. There was a thickened hyperpigmented lesion at the base of the growth (figure 1). A clinical diagnosis of $\mathrm{CH}$ was made. The growth was excised along with the base under local anaesthesia. The underlying skin defect was allowed to heal by secondary intention (figure 2). On histopathological examination (HPE), the diagnosis of $\mathrm{CH}$ was confirmed with features of seborrheic keratosis at the base (figure 3 ). The wound healed well without any recurrence 1.5 years after the operation (figure 4).

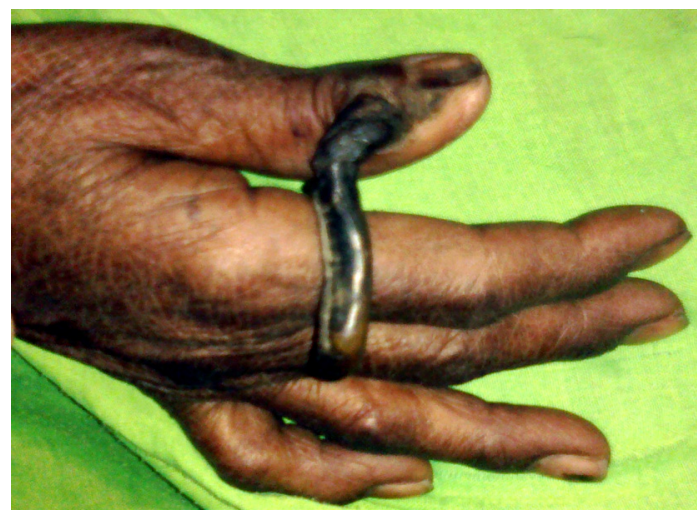

Figure 1 Preoperative colour figure showing giant cutaneous horn on thumb.

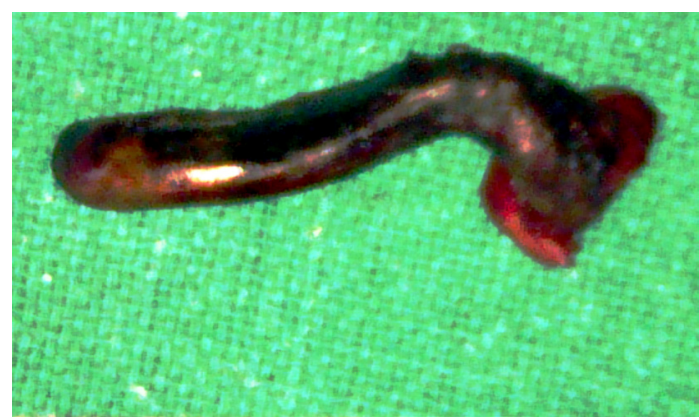

Figure 2 Excised specimen of giant cutaneous horn of thumb.

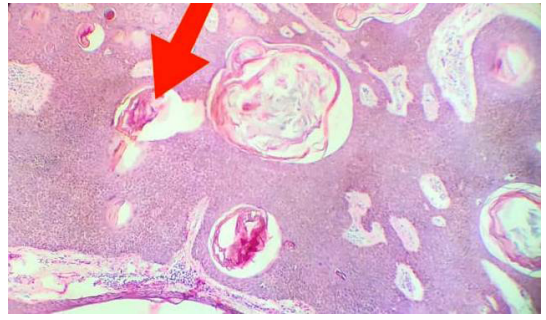

Figure 3 Epidermis shows hyperkeratosis and acanthosis with multiple horny pseudocysts made of loose keratin $(H \& E \times 100)$.

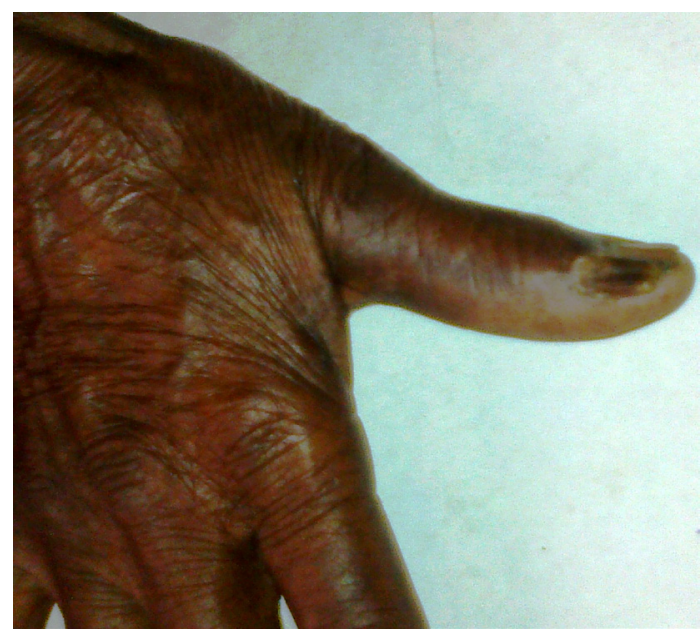

Figure 4 Follow-up photograph after 1.5 years showing no recurrence.

CHs (keratotic) are hyperkeratotic projections of the skin resembling the horn of an animal. ${ }^{6}$ All animal horns except those of rhinoceros contain bone cast. ${ }^{3} \mathrm{CH}$ in human beings in contrast does not contain bone cast and is exclusively composed of compact keratin. ${ }^{3}$ The pathogenesis of the lesion has not been fully understood. The base of the $\mathrm{CH}$ can harbour a wide variety of histopathological findings ranging from benign, premalignant to malignant. ${ }^{6}$ The features of an invasive squamous cell carcinoma presenting as a $\mathrm{CH}$ are height less than the diameter of the base, painful lesion, terrace formation at the side of the lesion and base of the lesion displaying erythema. ${ }^{7} \mathrm{CH}$ commonly occurs on the sun-exposed area or sites of chronic irritation of the body such as face, pinna, nose, forearm and dorsal aspect of forearm. A search of English literature did not reveal any case of $\mathrm{GCH}$ on the thumb.

The management of GCH requires wide local excision followed by careful HPE of the base. ${ }^{1-5}$ Further management depends on the underlying 
pathology whether benign or malignant. Long-term follow-up is required to detect any recurrence.

\section{Learning points}

- Giant cutaneous horn is rare on the thumb.

- The possibility of cutaneous horn harbouring malignant lesion at the base is nearly one-third, which should be kept in mind.

- Wide local excision with careful histopathological of the base is essential for adequate management.

Contributors MM and NKD were involved in patient management, drafted and revised the manuscript, did acquisition and interpretation of data. RKS drafted and revised the manuscript.

Funding The authors have not declared a specific grant for this research from any funding agency in the public, commercial or not-for-profit sectors.
Competing interests None declared.

Patient consent for publication Obtained.

Provenance and peer review Not commissioned; externally peer reviewed.

\section{REFERENCES}

1 Gupta V, Chopra V, Verma S. A large cutaneous horn of the glans penis: a rare presentation. Indian J Surg 2014;76:143-4.

2 M K, Kumar P, Pai MV. Giant cutaneous horn. Indian J Dermatol 2008;53:199-200.

3 Kumar S, Bijalwan P, Saini SK. Carcinoma buccal mucosa underlying a giant cutaneous horn: a case report and review of the literature. Case Rep Oncol Med 2014;2014:1-3.

4 Mantese SA, Diogo PM, Rocha A, et al. Cutaneous horn: a retrospective histopathological study of 222 cases. An Bras Dermatol 2010;85:157-63.

5 Copcu E, Sivrioglu N, Culhaci N. Cutaneous horns: are these lesions as innocent as they seem to be? World J Surg Oncol 2004;2:18.

6 Haddad CJ, Haddad-Lacle JE. Cutaneous horn: get to the bottom of it. BMJ Case Rep 2014; 2014:bcr2014204447.

7 Pyne J, Sapkota D, Wong JC. Cutaneous horns: clues to invasive squamous cell carcinoma being present in the horn base. Dermatol Pract Concept 2013;3:3-7.

Copyright 2019 BMJ Publishing Group. All rights reserved. For permission to reuse any of this content visit https://www.bmj.com/company/products-services/rights-and-licensing/permissions/

BMJ Case Report Fellows may re-use this article for personal use and teaching without any further permission.

Become a Fellow of BMJ Case Reports today and you can:

- Submit as many cases as you like

- Enjoy fast sympathetic peer review and rapid publication of accepted articles

- Access all the published articles

- Re-use any of the published material for personal use and teaching without further permission

\section{Customer Service}

If you have any further queries about your subscription, please contact our customer services team on +44 (0) 2071111105 or via email at support@bmj.com.

Visit casereports.bmj.com for more articles like this and to become a Fellow 